\title{
Mídias faladas locais: um estudo sobre atitudes linguísticas em Cáceres-MT
}

\author{
Local spoken media: linguistic attitudes in Cáceres-MT
}

\author{
Fernanda de Souza Pedroso Campelo ${ }^{*}$ \\ Universidade do Estado de Mato Grosso \\ Cáceres, Mato Grosso, Brasil \\ Jocineide Macedo Karim** \\ Universidade do Estado de Mato Grosso \\ Cáceres, Mato Grosso, Brasil
}

\begin{abstract}
Resumo: Este artigo tem por objetivo identificar atitudes linguísticas em relação às mídias faladas locais. Objetiva-se também identificar atitudes linguísticas em relação ao uso do falar cacerense na mídia falada de Cáceres-MT e aos usos linguísticos propagados em um programa de rádio de Cáceres-MT, o Banzé da Gatunada. As atitudes são sintetizadas em positivas (a favor desses usos) e negativas (contrárias a esses usos). As entrevistas com cacerenses nativos, que constituíram o corpus para análise, foram desenvolvidas por meio de perguntas abertas, baseadas nos estudos de Bisinoto (2000) e Lopes (2012). Os resultados obtidos corroboram nossa hipótese inicial de que os nativos apresentam atitudes linguísticas positivas frente aos temas a que nos propomos pesquisar.
\end{abstract}

Palavras-chave: Sociolinguística. Atitudes linguísticas. Variedades linguísticas. Mídias faladas locais. Mídia falada cacerense.

\begin{abstract}
This paper has as main objective to identify linguistic attitudes in relation to the spoken local media from the towns. The aim is also to identify linguistic attitudes in relation to the use of people of Cáceres way of speaking in the spoken media from Cáceres-MT and to the linguistic uses propagated in a radio program from Cáceres-MT, "Banzé da Gatunada". The attitudes are synthesized in positive (in favor of these uses) and negative (contrary to these uses). The interviews with native of Cáceres, which constituted the corpus for the analysis, were developed with opened questions, based on the studies of Bisinoto (2000) and Lopes (2012). The results obtained corroborate our initial hypothesis that the natives present positive linguistic attitudes in relation to the themes that we proposed to research.
\end{abstract}

Keywords: Sociolinguistics. Linguistic attitudes. Linguistic varieties. Local spoken media. Media speech of Cáceres.

\section{INTRODUÇÃO}

*Doutoranda do Programa de Pós-Graduação em Linguística - PPGL - Universidade do Estado de Mato Grosso, Cáceres, Mato Grosso, Brasil. E-mail: fernandaspedroso@hotmail.com.

** Professora do Programa de Pós-Graduação em Linguística - PPGL - Universidade do Estado de Mato Grosso, Cáceres, Mato Grosso, Brasil. E-mail: jocineidekarim@yahoo.com.br. 
A linguagem sempre inquietou o homem. Desde os primórdios, o sujeito busca entendê-la e conceituá-la. Dentre os seus estudiosos, podemos citar a relevância de Aristóteles e Descartes, que muito contribuíram para os estudos da linguagem. O primeiro focou no campo da retórica. Para ele, esta não se caracteriza no simples fato de persuadir, mas nos meios escolhidos para a persuasão. Assim, o sujeito deveria encontrar nas situações discursivas os subsídios persuasivos dispostos. Já Descartes caracteriza os signos. Para ele, os signos são arbitrários; dessa forma, não há relação dos signos com o que estes representam, ou seja, as palavras são nomeadas por arbitrariedade e não por convenção. Temos também a gramática de Port Royal, que considerava a língua produto da razão; dessa forma, as pessoas deveriam comunicar-se com clareza e precisão. Buscavase a língua ideal, na qual não houvesse equívocos, ambiguidade. Dessa forma, no decorrer dos anos, ao buscar explicar questões relacionadas à linguagem, muitas teorias surgiram, dentre elas a Sociolinguística.

A Sociolinguística busca explicar a relação entre linguagem e sociedade, evidenciando que a linguagem é reflexo das estruturas sociais. Para essa área da linguística a língua é heterogênea e está em constante processo de transformação, assim a Sociolinguística não vê a diversidade como um problema, uma vez que todas as línguas possuem variações.

Nessa perspectiva, filiadas aos pressupostos teóricos da Sociolinguística, buscamos identificar atitudes linguísticas de cacerenses nativos em relação ao falar das mídias locais, evidenciando se esses demonstram atitudes positivas ou negativas a respeito da ocorrência de variedades linguísticas regionais nos suportes midiáticos falados locais.

Este estudo surgiu do interesse em conhecer a concepção que as pessoas possuem das mídias faladas locais, buscando compreender os falares que são aceitos e recusados nessa mídia pelos ouvintes/telespectadores. Buscamos respostas a indagações como: 0 modo de falar nos jornais de rede influencia na preferência dos telespectadores em relação aos falares da midia local? Os telespectadores/ouvintes atribuem diferenças em relação ao falar da TV e do rádio local? Concernente ao uso de variedades linguisticas regionais, essas são aceitas nos falares da mídia local? $\mathrm{E}$ mais, o interesse por esse tema se deu porque acreditamos que criar um padrão de fala nas mídias locais consiste em reduzir as variedades linguísticas do município a somente um modo de falar. Assim, “[...] teremos nós - linguistas, gramáticos, professores, autoridades educacionais, meios de comunicação social, usuários do padrão em geral - de travar uma guerra ideológica ao normatismo" (FARACO, 2012, p. 41).

Pesquisas em atitudes permitem compreender os julgamentos e avaliações que os sujeitos fazem a respeito dos usos linguísticos, cabendo a nós sociolinguistas explicitar e esclarecer que os diferentes modos de falar não devem ser objetos de descrédito e preconceito.

Destarte, estudos que contemplem atitudes linguísticas são de extrema relevância para sociedade porque, por meio deles, compreendemos como se constroem os julgamentos em torno dos falares. Acreditamos assim que "[...] fazer pesquisa a propósito de língua não equivale a consultar gramáticas e dicionários para verificar o que neles consta e o que não consta neles" (POSSENTI, 2012, p. 15). Defendemos a relevância 
social desta pesquisa, pois a manutenção de uma variedade está intimamente relacionada às atitudes linguísticas dos sujeitos.

Nosso trabalho está dividido em três seções. Na seção 2, nomeada "Mídias faladas locais", discorremos sobre a ocorrência de variedades linguísticas regionais nas mídias faladas locais. Na seção 3, abordamos sobre o emprego da norma culta na mídia. Por fim, na seção 4, "Atitudes linguísticas em relação à mídia falada cacerense", expomos os dados obtidos e a análise desses, dessa forma, a referida seção exibe as atitudes linguísticas dos entrevistados em relação aos temas pesquisados neste estudo. O tópico está composto, pois, de gráficos, transcrições das falas dos inquiridos e análises dessas falas, com as quais evidenciamos atitudes linguísticas. Por último, socializamos as considerações finais desta pesquisa.

\section{MÍDIAS FALADAS LOCAIS}

O foco principal desta pesquisa foi identificar se os sujeitos apresentam atitudes linguísticas positivas ou negativas perante o uso de variedades linguísticas regionais nas mídias faladas locais e como os sujeitos avaliam e julgam essas ocorrências. Para tanto, elaboramos e aplicamos um questionário composto por questões que versavam sobre mídia falada local, buscando, por meio das respostas obtidas, identificar os julgamentos que as pessoas possuem em relação a essa mídia específica.

A relevância em pesquisar atitudes linguísticas perante as mídias locais ocorre porque os modos de falar propagados nessas mídias influenciam consideravelmente os falares das pessoas que têm contato com esses meios. A respeito dessa influência, Rodrigues (2012, p. 21) declara:

\footnotetext{
Além disso, como, por uma parte, os grupos profissionais do teatro, do canto erudito, do cinema, da rádio e da televisão têm particular interesse em superar as dificuldades que para uma atividade supraregional oferecem os regionalismos, o que nos leva a mais ou menos espontaneamente estabelecer padrões menos regionais de pronúncia, e como, por outra parte, esses mesmos grupos profissionais, e no Brasil mais particularmente o dos radialistas, podem influenciar fortemente o padrão ideal das regiões onde atuam, convém observar especialmente esses grupos não só com respeito a seus padrões de comportamento efetivo, mas também quanto ao padrão ideal que têm em vista.
}

Não buscamos avaliar se as atitudes linguísticas dos entrevistados estão certas ou erradas, mas compreender como as pessoas acreditam que devem ser os falares das mídias locais. Para Frosi, Faggion e Corno (2010, p. 23), "atitude, assim, pode ser entendida como a postura que um indivíduo assume frente a algo. Consiste, geralmente, em uma reação valorativa favorável ou desfavorável em relação a um objeto real ou simbólico". Mas as atitudes vão muito além, para Lambert (1975, p. 117), as atitudes não são simples sentimentos e crenças, têm influência considerável na nossa personalidade, ou seja, "[...] as atitudes que desenvolvemos formam padrões coerentes e que tais redes de atitudes contribuem para a estrutura de nossas personalidades". Na obra supracitada, o teórico defende que os estudos sobre atitudes são de grande relevância, uma vez que essas afetam 
diretamente o comportamento dos indivíduos na sociedade, assim pesquisas que contemplam as atitudes são de importância social.

Almejamos com esse estudo apresentar a relevância da inclusão de variedades linguísticas regionais nos suportes midiáticos falados locais, de forma a divulgar essas variedades e fortalecer os falares dos municípios. Porém Lopes (2012, p. 116) explica que há uma longa distância a ser percorrida para que esse nosso desejo se concretize na prática:

$\mathrm{Na}$ última década, com a valorização da interatividade e da espontaneidade, as emissoras estimularam a aproximação do telejornalismo das diferentes classes sociais, além de uma exposição, cada vez maior, nos jornais de rede, dos repórteres de diversas regiões do país. Junto com isso, uma tendência a maior aceitação das variantes regionais. Mas, entre o discurso de valorização dos regionalismos, a realidade prática das emissoras de televisão e o desenvolvimento profissional de repórteres/apresentadores, ainda há uma grande distância.

A fala de Lopes (2012) nos remete a Leite e Callou (2010), quando as autoras argumentam que ainda vivemos o passado, no qual os portugueses quiseram extinguir os falares dos indígenas. E, hoje, sujeitos que desconhecem a história e constituição da língua portuguesa tentam a todo custo homogeneizar essa língua, assim como fizeram os portugueses no período colonial. A esse respeito, elas concluem: "elege-se um padrão supranacional, do mesmo modo como se institucionalizou uma língua indígena como língua geral. E assim tudo continua” (LEITE; CALLOU, 2010, p. 63).

A língua faz parte da identidade ${ }^{1}$ de uma comunidade, logo os municípios devem manter suas variedades porque essas os diferenciam das demais regiões e as mídias locais, ao explorarem essas variedades em suas programações, contribuem para essa preservação e para não erradicação desses falares.

No entanto há uma tendência das mídias locais em se espelharem no modo de falar da mídia global, assim, na tentativa de seguir o padrão de fala direcionado pela mídia global, esses falares peculiares dos municípios acabam por serem impedidos. Isso é ressaltado por Silveira $\left(2006\right.$, p. 16) ${ }^{2}$ :

A partir dessas características conseguimos perceber que a mídia local, na maioria das vezes, não consegue explorar de forma adequada o local. Isto ocorre quando os meios de comunicação regional repetem os padrões e estratégias da "grande mídia" e inibem a valorização do local. Um exemplo disso ocorre nas televisões regionais onde muitas vezes o sotaque local do repórter é repelido.

Esses fatores contribuem para erradicação das variedades linguísticas regionais, pois, ao copiar o padrão de fala da mídia global, falares próprios do município são abandonados e, considerando que a interação com a mídia influencia nas atitudes

\footnotetext{
${ }^{1}$ Corroboramos o conceito de identidade o qual, ressoando Kramsch, Amâncio (2007, p. 41) explica: “[...] os falantes se identificam e identificam os outros através da sua língua é vista pelos falantes como um símbolo de sua identidade sócia".

2 Jornalismo esportivo na mídia local de Juiz de Fora: Os limites da cobertura sobre a campanha do Tupi em 2006.
} 
linguísticas e nos modos de falar dos sujeitos, ao deixar de usar falares da região para propiciar o uso do padrão imposto pela mídia, variedades regionais acabam por erradicarem-se. Sobre isso, Bisinoto (2000) argumenta que profissionais como professores, advogados, jornalistas e radialistas interferem de maneira decisiva no processo de mudança linguística. Essa influência da mídia nos usos linguísticos dos sujeitos também é explicada por Mollica (2012, p. 27), que descreve que fatores como "escolarização alta, contato com a escrita, com os meios de comunicação de massa, nível socioeconômico alto e origem social alta" contribuem para o uso na fala e na escrita das variedades de prestígio. Reforçando a influência dessas variáveis não linguísticas a autora argumenta:

[...] o efeito da mídia sobre as variantes de prestígio tem despertado interesse e tem sido objeto de estudo para verificar até que ponto há influência dos meios de comunicação nos comportamentos linguísticos (cf. Naro \& Scherre, 1996). As evidências estatísticas na referida coletânea sugerem que renda, valor de mercado, mídia e sensibilidade linguísticas, conjuntamente com outros parâmetros, podem ser bons indicadores sociais. (MOLLICA, 2012, p. 29)

A mídia estabelece poder tão significativo no modo de falar dos sujeitos que essa é considerada por Paiva (2012) como uma variável, nesse sentido, assim como as demais variáveis, a mídia exerce forte influência nos usos linguísticos das pessoas.

De forma diferente, constata-se que a variável mídia (em particular a televisão) possui efeito mais notável entre os falantes de sexo feminino, principalmente na quarta faixa etária (acima de 50 anos). Quanto maior o tempo de exposição à linguagem veiculada pela mídia, maior a ocorrência de variantes prestigiadas na linguagem das mulheres. (PAIVA, 2012, p. 39)

Assim, é preciso usar essa influência da mídia a nosso favor, ou seja, fazer uso das variedades regionais nas mídias faladas locais para que essas variantes não desapareçam. É preciso valorizar o local que sem sombras de dúvidas inclui a língua e, considerando que a língua é constituinte do sujeito, adotar um falar diferente da comunidade faz com que a mídia local não dialogue com a identidade daquele povo.

Contrariamente a isso, privilegiar os usos linguísticos regionais nas mídias faladas locais permite que se estabeleça uma proximidade entre apresentador e ouvintes/telespectadores. Isso acontece porque, como dito anteriormente, a língua faz parte da identidade de um povo, logo a presença dessas variedades linguísticas regionais nas mídias faladas locais permite que haja uma identificação da comunidade com a mídia, uma vez que "a língua, além de um instrumento de comunicação, é 'também um símbolo de identidade social ou de um grupo, um emblema de pertencimento e de solidariedade de um grupo" (FROSI; FAGGION; CORNO, 2010, p. 20 apud GROSJEAN, 2001, p. 117).

Contudo não é fácil colocar isso em prática, pois, ao longo da história, foi perpetuado outro discurso, o que reforça o preconceito em relação ao modo de falar dos sujeitos, intitulado como preconceito linguístico e os principais propagadores desse discurso, como retrata Bagno (1999, p. 14), trata-se da mídia e da escola: 
[...] o que vemos é esse preconceito ser alimentado diariamente em programas de televisão e de rádio, em colunas de jornal e revista, em livros e manuais que pretendem ensinar o que é "certo" e o que é "errado", sem falar, é claro, nos instrumentos tradicionais de ensino da língua: a gramática normativa e os livros didáticos.

Guedelha ratifica a posição de Bagno (1999), ao esclarecer que os meios de comunicação, a informática e a internet, ao invés de elevarem a autoestima dos falantes brasileiros, propagam mitos preconceitos ${ }^{3}$ em relação ao modo de falar das pessoas.

Todavia esse preconceito difundido e perpetuado pela mídia e escola não tem o mesmo valor e repercussão como os demais preconceitos, sejam eles de raça, cor, gênero, ou seja, o preconceito linguístico ainda há de ser considerado por muitos como um preconceito. Sobre isso, Possenti (2009, p. 22) explica:

Estigmatizar pessoas, candidatos ou não, com base em diferentes usos das línguas, é um preconceito equivalente aos preconceitos condenados pelas conhecidas declarações de direitos, como a da ONU, ou artigos de constituições, inclusive vigente no Brasil, que proíbem preconceitos de cor, raça, credo, ideologia, sexo etc. O preconceito linguístico, aquele em relação ao qual ainda não há clareza, nem mesmo por parte de intelectuais, até os de vanguarda e postados ao lado do povo, ainda precisa, no entanto, ser caracterizado como tal.

Em consonância com a declaração de Possenti, Scherre (2006, p. 40) almeja que um dia existam leis contra o preconceito linguístico, pois "pessoa alguma pode ser desrespeitada pela língua que fala”. Correlacionando o preconceito linguístico com o tema central do nosso estudo: atitudes linguísticas, pode-se afirmar que esses dois conceitos estão intimamente ligados, de modo que o preconceito linguístico é fruto das atitudes linguísticas dos sujeitos. Para Lambert, o preconceito é o principal exemplo de atitude, "pois sua significação social provocou muitas teorias e muitas pesquisas, e, além disso, o preconceito acentua os componentes essenciais em todas as atitudes" (LAMBERT, 1975, p. 100).

Considerando que, ao longo da história, houve uma abordagem da mídia em que se pregava pela suavização do sotaque, consequentemente, criou-se nos sujeitos uma atitude de que na mídia deve-se usar somente a norma culta ${ }^{4}$, livre de marcas regionais. Esse critério é explicado por Lopes (2012, p. 115):

Quando associamos isso ao telejornalismo e à variação linguística, precisamos ter a noção de que a suavização de características de fala regionais, que aconteceu em repórteres e apresentadores em todo o território nacional, tornou-se uma marca da forma de falar no telejornalismo, influenciada por determinantes históricos. Durante muitos anos, a forma de articular as palavras e o sotaque foram muito valorizados no trabalho de aperfeiçoamento de comunicação dos telejornalistas.

${ }^{3}$ Ver Crenças e atitudes linguísticas: um estudo dialetológico.

${ }^{4}$ Optamos, ao longo deste artigo, pelo termo 'norma culta', uma vez que concordamos com Bagno (2007), que explica que nenhum falante faz uso da norma padrão, mas sim da norma culta. 
Em oposição, enquanto sociolinguistas, reagimos favoravelmente aos usos linguísticos regionais nos jornais locais. Defendemos a valorização das marcas regionais nas mídias faladas locais, pois acreditamos que é uma forma de desenvolver atitudes linguísticas positivas frente ao próprio falar e, considerando que as atitudes atuam como um dos critérios para manutenção da língua, a ocorrência de variedades linguísticas regionais nas mídias locais propiciará atitudes positivas, consequentemente, ajudará a evitar a erradicação de muitos falares locais.

Considerando a força que as mídias locais possuem, insistimos que essas não devem somente apresentar conteúdos regionalizados, mas reiterar esse regional também na língua, pois entendemos que o local não inclui somente conteúdos mas também os falares da comunidade, reforçando, assim, a identidade, especificidade e singularidade de cada região.

\section{A NORMA CULTA NA MÍDIA}

Iniciamos esta seção explicitando a diferença entre dois termos que comumente são confundidos e, às vezes, tratados como sinônimos. Bagno (2007) esclarece que a norma culta diz respeito à variedade utilizada por falantes letrados, já a norma padrão trata-se de regras prescritas pelas gramáticas normativas. Percebe-se, assim, que a norma culta concretiza-se na língua, trata-se dos usos linguísticos de pessoas escolarizadas; já a norma padrão é um conjunto de regras, um modelo de língua que, na prática, não se consolida. Diante dessa conceituação, constata-se que nenhum falante faz uso da norma padrão. $\mathrm{Na}$ citação a seguir, o teórico explica por que é humanamente impossível fazer uso dessa norma:

Por isso, como também já dissemos, não faz muito sentido usar termos como variedade padrão, língua padrão, dialeto padrão, porque o padrão não é variedade, nem língua, nem dialeto - para tratar de variedade, língua e dialeto é preciso que existam pessoas de carne e osso falando essa variedade, língua ou dialeto, e ninguém fala (nem escreve) o padrão, nem no máximo grau de monitoramento estilístico. Como o próprio nome diz, é um padrão, um modelo idealizado (e muito ideologizado). Basta a gente comparar o molde de um vestido com um vestido de verdade, ou uma receita de bolo com um bolo que a gente pode pegar e comer. A norma padrão é uma "receita de língua", não é uma língua nem uma variedade real. (BAGNO, 2007, p. 131)

Ratificando nossa descrição de norma culta, Coelho; Gorski; Souza; May (2015, p. 141) explicam que "a norma culta não é formada, portanto, por um conjunto de preceitos dogmáticos, mas por variedades que já aparecem descritas nas boas gramáticas modernas e nos bons dicionários". Essa descrição de norma culta como usos linguísticos que ocorrem na realidade social é, para Bagno (2003), um termo técnico criado por pesquisadores profissionais. Por outro lado, a maioria das pessoas, para conceituar norma culta, inspira-se "[...] na longa tradição gramatical normativo-prescritiva" (BAGNO, 2003, p. 52). 
Bagno (2003) também adere à conceituação de norma padrão como um termo que não corresponde aos usos linguísticos dos falantes. "Ele serve muito bem, me parece, para designar algo que está fora e acima das atividades linguísticas dos falantes" (BAGNO, 2003 , p. 64). O teórico argumenta que, entre os termos língua padrão, dialeto padrão, e variedade padrão, ele prefere norma-padrão, pois se é algo ideal não representa nenhuma realidade linguística, dessa forma não pode ser língua, dialeto nem variedade. É, na perspectiva do autor, uma norma, pois corresponde a uma lei, é também um padrão, ou seja, um modelo.

Há diferentes abordagens em relação à norma culta e à padrão. Todavia é consenso entre os linguistas que a norma padrão trata a língua como se essa fosse homogênea e livre das influências internas causadas por seus interlocutores. Tratar a língua como homogênea é um grande equívoco. Para quebrar essa utopia, é preciso, segundo Bagno (2003, p. 19), "[...] olhar para a língua dentro da realidade histórica, cultural, social em que ela se encontra, isto é, em que se encontram os seres humanos que a falam e escrevem".

Para teóricos como Bagno (2003) e Camacho, a norma padrão é sinônima de poder, ou seja, a norma não está relacionada ao uso linguístico, mas ao sujeito que a utiliza. Dessa forma, a variedade padrão não se dá pelo uso propriamente dito da língua, a norma padrão é caracterizada de acordo com os falantes. Assim, essa norma está associada ao prestígio social do falante.

Ainda a respeito da norma padrão, muito se aborda e muitos são os trabalhos concernentes à supervalorização do ensino dessa norma e o apagamento das demais variedades linguísticas nas instituições de ensino. Apresenta-se que esse fato acaba por excluir os educandos que não utilizam essa variedade da língua, no entanto, assim como na escola, as mídias locais, ao supervalorizarem o uso da norma culta, fazem com que as variedades linguísticas locais percam espaço.

Nesse sentido, é imprescindível que, assim como os estudos direcionados ao ensino da língua portuguesa nas instituições escolares (que acabam por privilegiar somente a norma padrão e discriminar as demais variantes), se desenvolvam pesquisas apresentando a importância do uso de outras variedades, além da culta, nas mídias faladas locais, evitando, assim, a erradicação das variedades linguísticas, uma vez que, como a escola, a mídia também é capaz de acelerar esse processo. Sobre isso, Faraco (2008) assevera que as variedades designadas "[...] pela expressão linguagem urbana comum (PRETI, 1997)" (FARACO, 2008, p. 44) são dominantes nos meios de comunicação e no contexto escolar e "ainda hoje, apesar do que apresentam em contrário os nossos bons instrumentos normativos, é a norma curta que prevalece no discurso da escola, do senso comum e, principalmente, mídia" (FARACO, 2008, p. 65).

A mídia contribui significativamente na construção do nosso imaginário. Assim, quando as mídias locais deixam de utilizar os falares locais para privilegiarem e contemplarem somente a norma culta, é como se essas variedades locais não fossem importantes, mas, principalmente, a inibição dessas variedades nos suportes midiáticos falados locais faz com que os sujeitos acreditem que esses falares são errados, sendo assim não devem ser manifestados. A esse respeito Faraco (2008, p. 45) explica que: 
Como fruto das políticas homogeneizantes do Estado Novo getulista (1937-1945), nossos meios de comunicação social - o rádio, primeiro, e, depois a televisão - tenderam sempre a uma pasteurização da variedade linguística, barrando a presença, no seu espaço, da maior parte das variedades do português falado no Brasil. Só mais recentemente é que se começou a fazer menção à necessidade de dar espaço e audibilidade aos diferentes (assim chamados) sotaques brasileiros. Note-se, porém, que por "sotaques" normalmente se entende, neste tipo de discurso, não toda e qualquer variedade, mas apenas as diferentes pronúncias regionais das variedades urbanas tradicionais, ou seja, da linguagem urbana comum.

Assim, dada a constituição histórica da mídia que lutou veemente pela suavização dos sotaques dos profissionais desse meio $^{5}$ e pela manifestação da norma culta nos suportes midiáticos, criou-se um imaginário, em que os veículos de informação e comunicação devem adotar, em suas programações, somente essa norma. Isso está tão arraigado que a maioria das pessoas partilha dessa perspectiva. Esse julgamento é visível na fala dos entrevistados por Bisinoto (2000) em sua tese:

Perguntado, na questão 16, se um cacerense poderia realizar livremente seu falar característico no exercício de profissões como professor, advogado, locutor ou repórter de rádio ou TV, apenas um informante respondeu sim; $50 \%$ foram categóricos - não podem ou não devem; os outros $42 \%$ responderam que sim, mas com restrições, praticamente as mesmas apontadas pelos informantes nativos: depende do programa de rádio ou TV, da competência técnica do profissional, do público a que se dirige etc. [...] Alguns informantes procuraram justificar seu "não": "o professor não seria bem aceito, vai haver críticas. O advogado será ridicularizado. O repórter, então ... está fora de cogitação"; "haveria choque de cultura, as pessoas não vão entender"; "se eles falam assim, colocam uma barreira na frente, pelas divergências regionais"; “o pessoal cairia de pau em cima”. (BISINOTO, 2000, p. 83)

O preconceito linguístico é tão acentuado que se percebe na citação a seguir o quão crucial é o uso da norma de prestígio nas emissoras de TV do Brasil. Esta fala trata de uma resposta a uma pergunta proposta por Bisinoto (2000) concernente a episódios de discriminação sofridos por cacerenses correspondentes ao seu modo de falar: "Quanto à discriminação, 75\% afirmam conhecer várias histórias, mas apenas um se lembrou de um fato: uma reportagem interessante, produzida pela TV em Cáceres, que só não foi ao ar em circuito nacional porque o repórter 'puxava no sotaque' local”' (BISINOTO, 2000, p. 79).

É importante salientar que essas atitudes não foram encontradas em nossa pesquisa, ao contrário evidenciamos atitudes positivas frente ao uso de variedades linguísticas regionais nas mídias faladas locais. Talvez nossas respostas diferem das encontradas por Bisinoto (2000) porque, durante as entrevistas, deixamos claro que nossas perguntas contemplavam somente as mídias locais, buscamos identificar julgamentos frente aos usos linguísticos dessa mídia específica. Sobre a linguagem midiática, Calvet (2002, p. 76) expõe que "[...] a língua da mídia e da política pode influenciar os falantes que, diante dela, são

${ }^{5}$ Ver Lopes (2012): Preferências e atitudes dos ouvintes em relação à variação linguística regional no telejornalismo. 
apenas receptores, ouvintes? Em outros termos: 'Quais relações linguísticas os ouvintes mantêm com uma forma de linguagem que eles ouvem, mas não produzem?”.

No entanto, por mais que a mídia global tente sempre fazer uso da norma culta, outras variedades são manifestadas, basta observarmos com atenção que ouviremos comumente o uso de outras variantes, como a supressão do $r$ no final dos verbos, a alternância do $o$ pelo $u$ e, do $e$ pelo $i$ no final de palavras. Com ouvidos atentos, analisando minuciosamente, identificaremos esses usos linguísticos na fala de apresentadores e repórteres da rede nacional de comunicação. Isso acontece porque somos tomados pela língua e, por mais que monitoremos nossa fala, alguns usos linguísticos, como esses supracitados, são inevitáveis. A esse respeito Tarallo (2007, p. 58) explica: "ao ouvir um programa de rádio, ao assistir a um programa de televisão, ou ao ler um jornal, você observará que, apesar de todos os três procurarem refletir a norma-padrão, a presença de traços variáveis da fala se faz sentir".

Tarallo (2007) ainda explica que algumas programações privilegiam, sem intenção, o uso da variante não padrão, como: "[...] a transmissão de acontecimentos esportivos, os programas de auditório e as novelas" (TARALLO, 2007, p. 59). No primeiro exemplo, o teórico explica que essas variantes são manifestadas devido à simultaneidade entre o fato narrado e o momento da narração. Labov (2008) também explica em quais circunstâncias da mídia o vernáculo é manifestado:

Também é possível obter dados sistemáticos nas transmissões de rádio e televisão, embora aqui a seleção e os condicionamentos estilísticos sejam em geral muito fortes. Nos últimos anos, temos tido muitas entrevistas diretas no local de desastres, onde os falantes estão sob o forte impacto imediato do evento para monitorar a própria fala. Programas de entrevistas e discursos em eventos públicos podem nos dar bons cortes transversais da população, mas aqui o estilo é ainda mais formal do que obteríamos numa entrevista face a face. (LABOV, 2008, p. 246)

Diante do exposto nesse tópico, evidencia-se que os meios de informação e comunicação exercem forte relação de poder na sociedade, uma vez que, além de interferir no modo de vida das pessoas, influenciam na maneira de falar dos espectadores. "Somos muito mais influenciados pelas "modas" linguísticas da televisão e do rádio e, em menor escala, da imprensa escrita do que pelo trabalho estilístico dos autores de ficção" (BAGNO, 2003, p. 48). Dessa maneira, estudos que averiguem o poder da mídia sobre o modo de vida das pessoas e, principalmente, na criação de imaginários e na formação de atitudes, contribuem significativamente para quebra de estereótipos que os suportes midiáticos tentam a todo custo impor aos espectadores.

\section{ATITUDES LINGUÍSTICAS EM RELAÇÃO À MÍDIA FALADA CACERENSE}

Passamos agora à análise das respostas às perguntas 15, 23, 25 e 26 que revelam atitudes de trinta e seis nativos cacerenses sobre a mídia falada de Cáceres. 


\section{das Letras}

$\mathrm{Na}$ pergunta de número 15 indagamos aos nativos: Em relação à transmissão das notícias da cidade de Cáceres, você prefere escutá-las no rádio ou na televisão? Por quê??

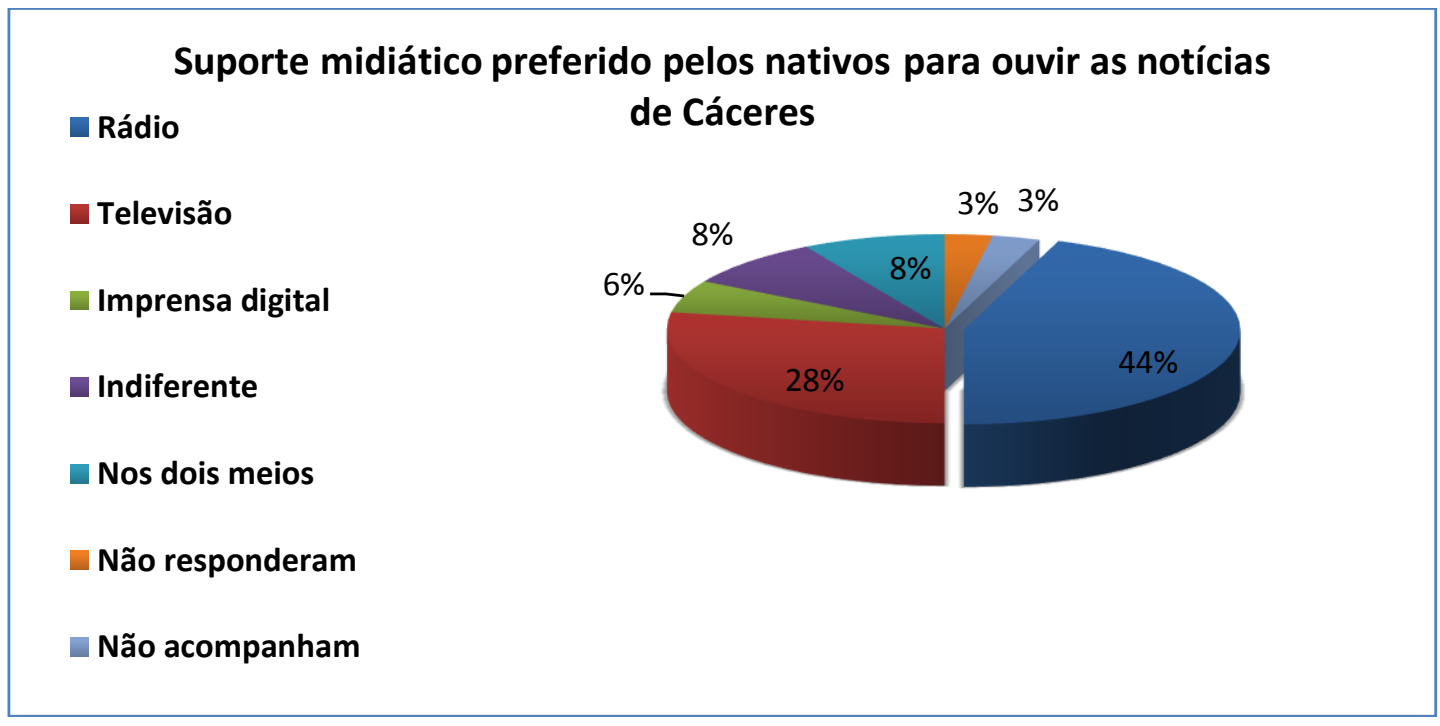

Gráfico 1: Suporte midiático preferido pelos nativos para ouvir as notícias de Cáceres

O gráfico expõe que a preferência dos ouvintes em relação à transmissão das notícias de Cáceres é pelo rádio, uma vez que 44\% dos informantes nativos disseram que preferem saber das notícias do município por meio desse suporte midiático; $28 \%$ por intermédio da televisão; $6 \%$ da imprensa digital; $8 \%$ disseram não ter preferência; $8 \%$ gostam e contemplam os dois meios de comunicação; 3\% não responderam; 3\% não acompanham as notícias.

A seguir elencamos a fala de alguns nativos que explicam por que preferem escutar as notícias de Cáceres no rádio, não se trata de uma escolha por um veículo de comunicação; para eles a mídia radialística de Cáceres é mais detalhista e explica melhor as notícias do município.

(1) Eu particularmente só escuto no rádio, na televisão pelo menos a emissora televisiva aqui de Cáceres não me chama muito atenção, mais é o rádio mesmo, que é bem mais acessível, mais rápido né e tem uma colocação melhor (Inf. 6).

(2) Eu acho qui no rádio é melhor porque no rádio passa mais notícias sobre as informações de Cáceres do que na tv na tv eu acho mais restrito num é não passa tanto, passa a informação mas eu acho que no rádio é, transmiti mais informação que na tv (Inf. 8).

(3) ... A eu, no rádio. Porque no rádio explica bem mais que na televisão, na televisão eu num gosto de assisti, daqui né, ( ) ele fala mais o que a o fato né, da TV só mostra um pouquinho i só num fala mais nada, pelo menos pra mim 
né, eu entendo assim, que eu num, eu gosto mais do rádiu, eu memo não assisto () TV (Inf. 11).

(4) A nu rádiu. A na TV é só propaganda, é meiu di comunicação é assim qui puxa mais pru ladu comercial né, financeiru que dizer, ladu financeiru, então é, é, di cada vinte propaganda qui elis têm, elis passa dois três di notícia, então eu prefiru o rádiu, fala mais notícia qui a televisão, eu prefiro pelo rádiu, na nossa, aqui em Cáceres (Inf. 13).

(5) Bom as notícias normamenti si ouvi mais é nu rádiu, na TV infelizmenti a TV não dá regra geral é boas notícias, infelizmenti a mídia é a má notícia qui é notícia né, na televisão, então é no rádiu é mais fácil, é mais comum ouvi notícias da cidadi né, noticiárius pela manhã, normalmenti pela manhã si tem mais, mais acessu (Inf. 17)

(6) Nu rádiu. A porque tem uns programa bem divertidu, rs qui informa, qui é informativu, mas qui também tem humor na forma delis informá, nu jeitu delis (Inf. 34).

Na pergunta 15, foram propostas aos informantes duas opções: televisão ou rádio, no entanto alguns manifestaram que acompanham as notícias do município por meio da imprensa digital, como explanado nos depoimentos abaixo:

(7) Eu não veju TV local, eu prefiru na, eu prefiru através da imprensa digital. Eu prefiru mídia digital pra sabe das notícias de Cáceris (Inf. 15)

(8) Não escuto nenhum dos dois, olho pela internet, mas não (), né (Inf. 19).

Por fim, conforme explanado no Gráfico 1, os cacerenses entrevistados têm preferência em escutar as notícias do município pelo rádio. Argumentam que essa mídia é mais detalhista e minuciosa.

Os gráficos seguintes foram confeccionados por meio das respostas à pergunta: Você ach a correto falar do jeito cacerense na TV ou no rádio? Por quêe? 


\section{Revista

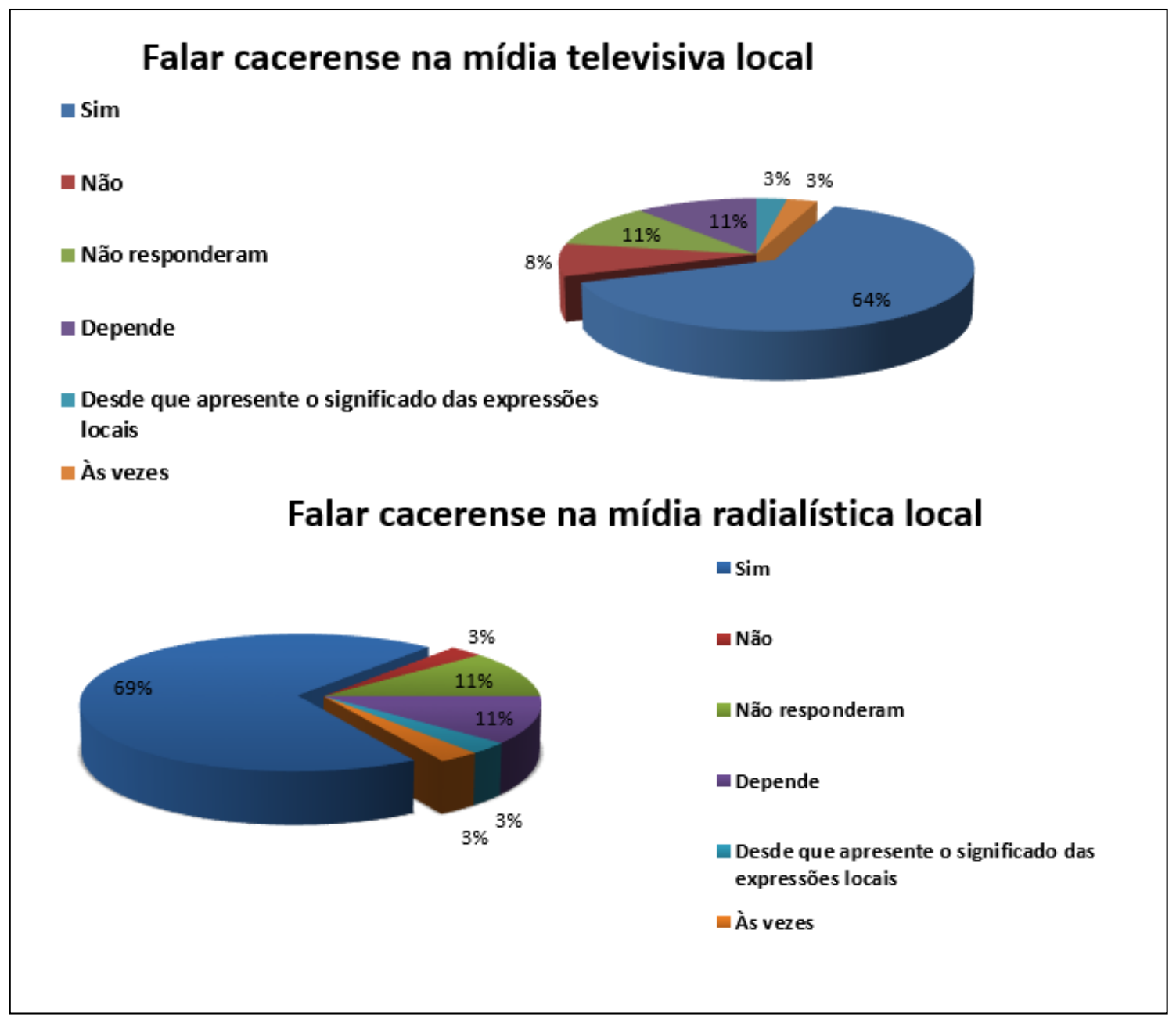

Gráfico 2: Falar cacerense na mídia televisiva local 10b: Falar cacerense na mídia radialística local

Os dados distribuídos ao lado esquerdo do Gráfico 2 mostram que 64\% dos nativos são favoráveis ao uso do falar cacerense na mídia televisiva local; $8 \%$ são contrários; $11 \%$ disseram que isso depende da programação; $3 \%$ são favoráveis desde que se apresente o significado das expressões locais aos ouvintes; $3 \%$ responderam que às vezes.

Ao lado direito do gráfico, temos informações sobre a aceitação do falar cacerense na mídia radialística local. Os dados revelam que $69 \%$ dos nativos são favoráveis ao uso do falar cacerense nessa mídia; $3 \%$ são contrários; $11 \%$ não responderam; $11 \%$ disseram que isso depende da programação; $3 \%$ são favoráveis desde que se apresente aos ouvintes o significado das expressões locais; $3 \%$ responderam que às vezes.

Determinadas respostas à pergunta $23^{6}$ merecem uma análise minuciosa e criteriosa, uma vez que algumas revelam estereótipos por parte dos nativos e, estigmas e

${ }^{6}$ Você acha correto falar do jeito cacerense na TV ou no rádio? Por quê?? 
preconceitos por parte "dos outros". Iniciaremos as análises com as falas dos informantes que se mostraram favoráveis ao uso do falar cacerense nas mídias faladas locais:

(9) Eu acho porque é a fala normal só é um pouquinho engraçada né (Inf. 3).

(10) A eu achu correto, eu achu correto porque atrai é, atrai o público e coloca o público assim sem uma discriminação, né não tem aquela discriminação, eu acredito que é interessanti porque coloca o povo mais próximo né (Inf. 10).

(11) É eu achu né porque é filho da terra né tem qui falá do jeito que aprendeu né, mas se pudé consertar um pouquinho a mais algum erro né, tem que consertá, não fica sempre naquilo mesmo né, tem qui () (Inf. 12).

(12) Sim porque se eu não achasse, eu teria qui desqualificar tudo o que eu disse anteriormenti, entendeu, eu achu qui a forma di fala é o que identifica aquele povu, entendeu, i eu acho qui a genti não tem qui desqualificar a questão linguística ou qualquer outra questão é relacionada a língua, ( ) então eu achu qui não, eu achu qui as pessoas tem qui ter o pontu (), né, di saber o qui estão fazendu, se for transmiti notícia a forma como eu vou falá tem qui se de uma forma formal, entendu e o por isso as pessoas precisam de formação adequada, agora o sotaque que você vai utilizá, entendeu, si é regional, si não é regional, você precisa fazer com qui as pessoas intendam né, agora, não achu qui tenha problema i não achu qui devi desqualificar o trabalho de alguém qui eventualmenti tenha um sotaqui carregadu (Inf. 15).

(13) Comu?. A eu achu. Porque tá mostranu comu é, us cacerensis aí quem vê di outru lugar assim vai achá feiu mas comu a genti já acostumô, então tem qui tê o sotaqui cacerensi mesmu (Inf. 30).

$\mathrm{Na}$ fala da informante (3), observamos a caracterização do falar cacerense como engraçado. O informante (10) levanta uma questão relevante ao abordar que usar o falar cacerense na mídia local aproxima mais o ouvinte da programação; já a fala da informante (12) revela um estereótipo: de que o falar cacerense é errado. O informante (15) elencou algo importantíssimo quando afirma que, se fosse contrário ao uso do falar cacerense na mídia local, ele acabaria por contradizer suas respostas anteriores. Cabe destacar que isso aconteceu com alguns informantes que se contradisseram em suas respostas, ou seja, alguns, em resposta às questões 19, 20 e $22^{7}$, se mostraram favoráveis às ocorrências de sotaques e usos linguísticos regionais nas mídias faladas locais; todavia, em relação à ocorrência do falar cacerense na mídia de Cáceres, não apresentam as mesmas atitudes.

Por fim, a fala da informante (30) revela um preconceito, não por parte do nativo, mas por parte do migrante que descreve esse falar como feio.

Elencaremos agora a fala dos informantes que relataram que esse critério depende da programação que será veiculada. $\mathrm{Na}$ fala desses nativos, percebemos um estigma em

719) Você acha que os locutores de rádio podem apresentar sotaques regionais em suas falas durante as programações? Por quê?; 20) E nos jornais locais, você acha que os apresentadores e repórteres podem apresentar o sotaque regional em suas falas? Por quê?; 22) Você acha que na TV e no rádio os apresentadores, repórteres e locutores podem utilizar falares característicos do município? Por quê? 
relação ao falar cacerense, uma vez que tal falar não pode ser manifestado em situações sérias, para $11 \%$ dos entrevistados sempre que a notícia ou a programação exigir um caráter mais sério, o falar cacerense deve ser inibido.

(14) Não, não é bem correto mas, mas dependendo, mais uma vez dependendo das circunstâncias que promovem as notícias né, se for uma notícia que demanda é, uma maior seriedade no caso, realmente tem que ter uma certa formalidade, caso contrário ela permanece de forma simples né (Inf. 6).

(15) É igual eu falei eu acho eu acho qui depende da situação ou acho que se for di um telejornal um jornal di qui seja né para informações mais, informações política informações mais séria eu acho qui tem que se é correto porque do jeito certo tudo bunitinhu mas se for de uma maneira de entreterimento di di alguma programação qui não exija né qui seja assim eu acho que não não tem problema (Inf. 8).

Para os informantes 6 e 8, na exposição de notícias sérias, não se pode usar o falar cacerense, já em outras situações não há problemas se esse falar aparecer. É como se o falar cacerense fosse antônimo de seriedade, uma vez que, nessas circunstâncias, esse falar não deve ser manifestado. Acerca disso, Bisinoto (2000, p. 72) ressalta:

Quando desaprovam ou limitam o uso de seu próprio falar em atividades profissionais ou apresentações públicas, os nativos dão legitimidade ao estigma que desfavorece o falar cacerense dentre as demais variedades em contato. Essa discriminação também é consciente, pois reconhecem - e manifestam isso reiteradas vezes - que os demais falares se realizam livremente em Cáceres, têm aceitação social, não sofrem censura.

A fala da informante 18 também se enquadra no perfil dos nativos que disseram que depende da programação para que esse falar possa ser manifestado. Porém, seus argumentos diferem dos dois informantes anteriores, os quais expuseram que, em circunstâncias que exigem mais seriedade, o falar cacerense deve ser inibido. Para a entrevistada essas variedades regionais podem ser utilizadas se o programa for específico para isso. Além disso, a informante expõe que se preocupa com o uso dessas variantes porque a mídia, assim como a escola, também educa. Dessa forma, ela argumenta:

(16) Bom, dependi, bom tirandu essas variantis qui são marca du falar por exemplu cacerensi qui são o che, o jê e u on ( ) normalmenti, tem pessoas qui falam pranta, mas u locutor eli também educa, né, então eli tem responsabilidadi com a língua, aí tem que ver, dependi du programa né, si é um programa específicu pra utilizar essas variantis, tudo bem, mas normalmenti eu pensu qui u locutor tem que primar por essa norma culta, porque eli nos ajuda, por exemplu enquantu educadores, rádiu, televisão, né, essa mídia mas () a população, tem mais, gostam di assistir di ouvir, então é um meiu di ajudar nessa questão da delis adquirirem essa outra varianti não só delis né, mas de todas as pessoas (Inf. 18). 
Os informantes 6, 8 e 18 selecionam alguns critérios para o uso do falar cacerense na mídia falada local, ou seja, restringem esse falar a determinadas situações. Isso nos remete ao tópico 6 da dissertação de Bisinoto, intitulado "atitudes perante sua própria fala" no qual a pesquisadora expõe:

Sobre sua própria aceitação do uso do falar cacerense em atividades profissionais ou apresentações públicas (na escola, no rádio, na TV, numa palestra (questão 9)), 25\% não vêem nenhum problema ou inconveniência em que as pessoas falem do seu jeito em qualquer lugar; $42 \%$ acham inaceitável o uso do falar nas circunstâncias sugeridas e $33 \%$ o aceitam, mas com restrições: depende do programa de rádio ou TV, do horário, da platéia, do nível de conhecimento de quem fala, da escola ("em escolas particulares, aceita-se muito menos o falar cacerense" (N-PLP)). Alguns informantes lembraram que os outros falares se ouvem em Cáceres nessas situações sem sofrer restrições ou reprovações. (BISINOTO, 2000, p. 72)

No depoimento (17), o informante explica por que é contrário ao uso do falar cacerense na mídia falada de Cáceres. O nativo avalia esse falar como errado e considera que, assim como a escola, a mídia também educa, logo ambas devem usar a linguagem "correta":

(17) Não, eu acho porque o cacerense fala erradu, ele deixa muita palavra pra trás, igual falei para você tem certas coisa que ele não compreta a palavra. Locutor tem que, olha é até difícil de respondê essa palavra, porque geralmenti quando se fala em jornalismo eles procura falá o certo né, porque a televisão até porque ela faz parte da educação pra nois né, a televisão o rádiu o que seja né, tem que procurá falá certo pra genti tá acompanhanu eles, mais já que existi essa cultura aqui...tem que procura puxá sempre pru ladu da fala cacerense. Eu achu (Inf. 13).

Assim como o informante (13), a fala da informante (2) revela que essa acredita que o falar cacerense é errado: "Ele tem que ter uma linguagem diferente acho que assim mais certo assim" (Inf. 2).

A informante (29) é favorável à manifestação desse falar na televisão e no rádio de Cáceres, mas acredita que haverá estigma por parte dos ouvintes:

(18) Intão, é nessa questão qui ti falei, se favorável, sim im pontu porque tem pessoas qui ama nossu jeitu, mas aí () nós aqui é um país di divisa, um país qui a genti, um país, um municípiu di divisa, um municípiu qui nós temus muitas outras pessoa né, então, qui vem pra cá, i aí eu acreditu () di debochi se utilizá só nossa língua, entendeu a nossa forma di falá nu rádiu televisão (Inf. 29).

Por fim, alguns informantes, no momento das respostas, diferenciaram a televisão e o rádio, sendo favoráveis ao falar cacerense somente no segundo suporte midiático: 
(19) É, nu rádiu podi sim, achu qui podi, mas não TV num podi. A porque nu rádiu já é mais uma coisa na brincadeira né, por mais qui seja sériu i tal tem qui sair bunitu, mais as pessoa gostam na brincadeira (Inf. 28).

(20) Não, na TV não. Fica tirandu muitu saru, () as pessoa num fala né, qui é daqui num fala, mas di fala (Inf. 36).

$\mathrm{Na}$ fala dos nativos, o que nos chamou atenção foi que, no primeiro caso (Inf. 28), o entrevistado revela ser favorável ao falar cacerense no rádio porque a mídia radialística abrange a brincadeira, ou seja, mais uma vez há revelação de atitudes em que o falar cacerense é manifestado na mídia cacerense nessas situações; já o informante 36 é contra o falar cacerense na televisão local porque as pessoas irão "tirar sarro desse falar". Repetese aqui também o estigma por parte do outro.

O fato do falar cacerense, na maioria das vezes, ser manifestado somente em situações humorísticas explica, em parte, as atitudes dos informantes os quais relatam que esse falar deve ser evitado em situações que exigem um maior grau de seriedade e manifestado em programas de entretenimento.

A informante 21 aborda que às vezes a mídia promove situações de desprezo para com o falar cacerense e com as pessoas que utilizam esse falar. Assim, nem sempre a entrevistada é favorável ao uso do falar cacerense na mídia local, porque algumas vezes a manifestação desse falar na mídia só gera mais preconceito, devido à maneira como é trabalhada, assim a informante expõe que:

(21) Mais ou menus, porque a é tem algumas ( ) qui elis às vezis elis falam assim meiu qui disprezandu né u u u, as pessoas né, assim determinadus sotaquis qui elis usam, determinadas linguagens qui elis usam, eu achu qui às vezis elis é pegam um pouco pesadu, acaba assim agredindu sem sabê né ou sei lá sem intenção (Inf. 21).

No entanto, como se pode observar nos dados dispostos no gráfico, a maioria dos nativos entrevistados demonstrou atitudes positivas frente ao uso do falar cacerense na mídia falada local. Houve sim algumas falas que revelam estigma e estereótipos por parte dos nativos, todavia, de uma forma em geral, a maioria dos informantes relata ser favorável ao uso desse falar na mídia falada do município.

Prosseguindo com as análises, a pergunta de número 25 do questionário indagava: $V$ ocê considera que o falar apresentado em algum programa de rádio em Cáceres se assemelha com o falar cacerense? Por quê? Obtivemos o resultado disposto no próximo gráfico: 


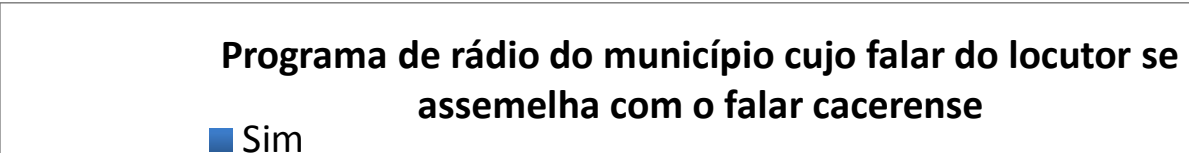

Sim assemelha com o falar cacerense

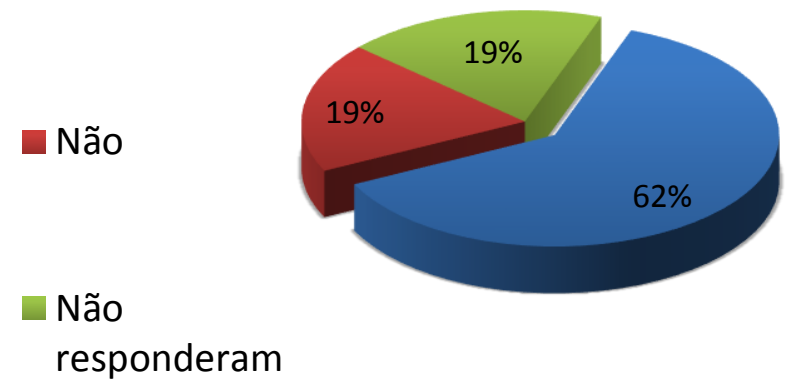

Gráfico 3: Programa de rádio no município cujo falar do locutor se assemelha com o falar cacerense

O Gráfico 3 mostra que $62 \%$ dos informantes responderam sim; $19 \%$ não; e os outros 19\% não responderam. Dentro dos 62\% dos informantes que acreditam que há na cidade um programa cuja fala do locutor se assemelha à cacerense, 11 informantes, ou seja, 31\% citaram o Banzé da Gatunada e explicaram por que o falar propagado nesse programa parece com o falar local. Os depoimentos seguintes expõem claramente isso:

(22) Urum. Tem do Banzé da Gatunada ( ) mais cacerense é típico daqui memo. O jeito dela falar assim meio rápido i engraçado também (Inf. 2).

(23) Sim se assemelha no caso do programa do Pedro Miguel $^{8}$ que é bem parecido, bem parecido mesmo é o único na verdade (), eu falo que é o único porque depois do jornal, depois dessa notícia do chamado Banzé da Gatunada tem o jornal do Faquini né que é um jornal que é um pouquinho mais formal totalmente diferente da colocação da qual o Pedro Miguel faz (Inf. 6).

(24) Sim u u da manhã, o Banzé da Gatunada lá. Ocorrência policial que eles fala, a ele fala muito num na numa forma numa forma cacerensi de se mesmo entendeu, ele fala bem puxado tipu, o cacerensi ele num não ele num nega assim nada assim ( ), não ele fala aquilo que ele pensa e é daquele jeito i deu certo o pessoal gosta de ouvi, eu gosto de ouvi. Onde você vai as pessoas comentam que nem chega, as pessoas ouvem mesmo, [...] (Inf. 7).

(25) Hurum, tem...é pur exemplo, sendo aqui mesmo de Cáceres?, a tem a difusora né, tem esse aí da manhã cedo que é o Pedro Miguel que apresenta que ele passa tudu os noticiário de morte () tudo isso né, sete e meia da manhã. Porque eles falam assim, o jeito de ser né, aqui de Cáceres, qui aqui eu acho qui por exemplo quando a pessoa tem o hábito de falá, ele não muda né, de jeito nenhum (Inf. 12).

${ }^{8}$ Pedro Miguel é o locutor que apresenta o programa Banzé da Gatunada, dessa forma, quando os informantes mencionarem esse nome, estão referindo-se ao referido programa. 


\section{das Letras}

(26) É existi u u, uma locução, agora não me lembro o nomi do locutor, muito meu amigo inclusivi qui eli tenta brincar na questão policial com algumas falas nossas, alguns, não é só o sotaqui, mas algumas falas nossas, qui eli não tem o sotaqui sotaqui (), mas eli tem alguns dizeres du povu cacerense. É o rapaz do ripa nos malandrus, qui escreve os ripa nos malandrus, o nomi desse jornal nossu aqui () (Inf. 14).

(27) Esse programa qui eu dissi, que eu também não sei o nomi, apresentadu pelo Pedro Miguel, é um programa qui ele tra, eli faz um rotero das ocorrências policiais, você entendeu, usando um sotaqui muitu carregadu, até eli exedi um pouco, mas justamenti pra torna aquilu cômicu, mas representa muitu bem é, a forma como as pessoas, os cacerensis, pricipalmenti os mais antigus falam, inclusivi com algumas palavras, algumas terminologias qui a genti até tem dificuldade pra intendê (Inf. 15).

(28) Sim u Pedro Miguel memu, tem a a a linguagem bem cacerensi. A é u jeitu arrastadu di falé né (Inf. 20).

(29) Esti, Banzé da Gatunada. A tudo, tudo qui eli fala, a linguagem deli é cacerensi mesmu. Agora não sei si é pra chamar atenção também né (Inf. 33).

(30) Só tem essis dois mininu, se vê aquela rádiu de lá di cima, u pessual só fala diferenti, só tem aqui u Faquini i u Pedru Miguel, si intendeu. Tem outru meninu qui tem aqui também qui fala u quase linguajar nossu, qui é cacerense memu também, tem aqueli outru meninu qui é du du du daqueli programa di música, intendeu, também é dia fora mas veiu piquenu pra cá, já fala u nossu linguajar, tendeu (Inf. 35).

Corroborando a pergunta 25, o intuito da questão 26 era evidenciar qual programa difundido em Cáceres-MT melhor representa esse falar peculiar e original do município. Assim questionamos aos informantes: Qual programa de rádio aqui de Cáceres-MT melhor representa o falar cacerense?

\section{Programa de rádio do município que melhor representa o falar cacerense}

Banzé

Edimilson Tavares

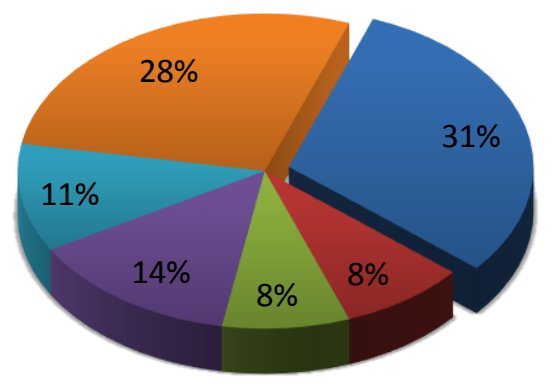

não lembraram o nome do programa e locutor

Não souberam informar 


\section{Gráfico 4: Programa da rádio do município que melhor representa o falar cacerense}

Conforme revelado no Gráfico 4, 31\% dos informantes disseram que o programa de rádio difundido em Cáceres-MT que melhor representa o falar da comunidade é o programa Banzé da Gatunada; 8\% disseram que o locutor que melhor representa esse falar é o Edimilson Tavares; $8 \%$ dos entrevistados mencionaram o nome de outros locutores, sendo eles: Faquini, Hildefonso Rosa, Di Carlos, Di Jalma, e uma informante disse Clube FM, ou seja, cada informante falou o nome de um locutor diferente. Não houve, assim, mais de um voto para esses locutores; como no caso do Edimilson Tavares e do Banzé da Gatunada; $14 \%$ dos nativos disseram que nenhum programa representa esse falar; $11 \%$ relataram que há programas no município que representam esse falar, mas esses entrevistados não sabem o nome do programa, nem do locutor; $28 \%$ disseram não saber informar se há no município um programa que represente esse falar. Essa porcentagem refere-se a informantes que não escutam rádio, ou o fazem eventualmente, dessa forma não sabem informar se há esse tipo de programa no município.

Expomos, nessa seção, atitudes linguísticas frente à mídia falada cacerense e em relação ao uso do falar cacerense nessa mídia. Evidenciamos que o suporte midiático de Cáceres preferido dos nativos entrevistados é o rádio (44\%); o programa da mídia de Cáceres que melhor representa o falar local é o Banzé da Gatunada (31\%). E, indagados se acham correto usar o falar cacerense na TV e no rádio do município, 64\% dos inquiridos são favoráveis a esse uso na TV e $69 \%$ são a favor desse falar no rádio.

\section{CONSIDERAÇÕES FINAIS}

Este estudo buscou compreender atitudes linguísticas em relação aos falares das mídias locais, evidenciando os usos linguísticos que são aceitos nessas mídias. As atitudes, em sua maioria, revelaram sentimentos positivos perante o uso de falares locais.

Diante do exposto, percebe-se que as atitudes identificadas nas entrevistas corroboram nossa hipótese inicial, em que julgávamos que os informantes apresentariam atitudes positivas frente à ocorrência de usos linguísticos regionais nas mídias faladas locais. A esse respeito colocamos em relevo que esses dados nos deixaram extremamente satisfeitos, pois consideramos que as atitudes não são simples julgamentos, mas influenciam na permanência ou erradicação de um falar.

Em relação à ocorrência de variedades linguísticas regionais nas mídias faladas locais, os informantes mostraram-se favoráveis, argumentaram que esse critério permite maior integibilidade das informações e uma identificação da comunidade com a programação. Entretanto, essas atitudes são um diferencial do nativo de Cáceres, pois, em sua pesquisa, Lopes (2012, p. 115) identificou que:

O telespectador, por sua vez, não é isento nesse processo. Nesses dez anos de trabalho com aprimoramento da comunicação de telejornalistas, muitas vezes, fomos indagados por telespectadores sobre a forma de falar "arrastada" ou sobre a pronúncia regional de determinado repórter ou apresentador local. O fato interessante é que é exatamente o ouvinte 
nativo da região que se queixa de ver a sua forma de falar representada na fala do telejornalista.

Assim, como explica Lopes (2012), os telespectadores não são isentos do processo de suavização dos sotaques, pois as atitudes negativas em relação à ocorrência de marcas regionais contribuem para que as emissoras continuem prezando pela inibição de aspectos regionais nas falas dos profissionais da mídia. Evidencia-se assim que não se trata de um critério somente primado pelas emissoras, uma vez que, pelo exposto, os próprios ouvintes não apreciam a ocorrência de variedades regionais na fala dos profissionais da mídia. O pesquisador identificou, também, que os sujeitos tendem a transferir aspectos da mídia global para as mídias locais e dessa forma prezam pela não ocorrência de marcas linguísticas regionais. A esse respeito o teórico esclarece:

Vale salientar que a constituição histórica da forma de falar dos telejornalistas acabou por se distanciar da fala conversacional, criando um estilo próprio que caracteriza os falantes desta categoria profissional. O que acontecia em Rede acabou sendo transferido para as realidades locais, de modo que os repórteres e apresentadores locais passaram a adotar (ou a buscar) uma forma de falar suavizada, em termos da não ocorrência de características regionais (LOPES, 2012, p. 114)

No entanto, conforme evidenciado em nossos dados coletados, as atitudes dos nativos de Cáceres divergem do exposto por Lopes (2012). Por fim, ansiamos que este estudo possa contribuir para o desenvolvimento de pesquisas sobre atitudes e em relação ao falar das mídias locais. Argumentamos a favor da relevância deste estudo no sentido de que é importante saber como as pessoas julgam as variedades linguísticas empregadas na sociedade e mais especificamente na mídia, pois as atitudes propiciam a erradicação ou a permanência dos falares.

\section{REFERÊNCIAS}

BAGNO, Marcos. Preconceito linguístico. O que é, como se faz. São Paulo: Loyola, 1999. 2004. . Português ou brasileiro? Um convite à pesquisa. $4^{\mathrm{a}}$ ed. São Paulo: Parábola Editorial,

- Nada na lingua é por acaso: por uma pedagogia da variação linguística. São Paulo: Parábola Editorial, 2007.

BISINOTO, Leila Salomão Jacob. Atitudes sociolinguísticas em Cáceres-MT: efeitos do processo migratório. Dissertação de Mestrado. Campinas: Unicamp, Instituto de Estudos da Linguagem, 2000.

CALVET, Louis-Jean. Sociolinguística: uma introdução crítica. São Paulo: Parábola, 2002.

CAMACHO, Roberto Gomes. Norma culta e variedades linguísticas. Disponível em: https://edisciplinas.usp.br/pluginfile.php/174227/mod resource/content $/ 1 / 01 \mathrm{~d} 17 \mathrm{t} 03$. pdf. Acesso em: 29 abr. 2016.

FARACO, Carlos Alberto. Norma culta brasileira: desatando alguns nós. São Paulo: Parábola Editorial, 2008. 


\section{Revista

Norma-padrão brasileira: desembaraçando alguns nós. In: . Linguística da norma. $3^{\text {a }}$ ed. São Paulo: Edições Loyola, 2012.

FROSI, Vitalina Maria; FAGGION, Carmen Maria; CORNO, Dal Mantovani Olivia Giselle. Estigma: cultura e atitudes linguísticas. Caxias do Sul: Educs, 2010.

LABOV, William. Padrões sociolinguisticos. Tradução de Marcos Bagno, Maria Marta Pereira Scherre e Caroline Rodrigues Cardoso. São Paulo: Parábola Editorial, 2008.

LAMBERT, W. E. L. A significação social das atitudes. In: . Psicologia social. $5^{\mathrm{a}}$ ed.

Trad. D. Moreira. Rio de Janeiro: Zahar Editora, 1975, p. 98-135.

LEITE, Yonne. CALLOU, Dinah. Como falam os brasileiros. $4^{\mathrm{a}}$ ed. Rio de Janeiro: Zahar, 2010 .

LOPES, Leonardo Wanderley. Preferências e atitudes dos ouvintes em relação à variação linguística regional no telejornalismo. João Pessoa, 2012.

MOLLICA, Maria Cecília; BRAGA, Maria Luiza (Orgs). Introdução à sociolinguística: o tratamento da variação. $4^{\mathrm{a}}$ ed. São Paulo: Contexto, 2012.

PAIVA, Maria da Conceição de. A variável gênero/sexo. In: MOLLICA, Maria Cecília; BRAGA, Maria Luiza (Orgs). Introdução à sociolinguística: o tratamento da variação. $4^{\mathrm{a}}$ ed. São Paulo: Contexto, 2012.

POSSENTI, Sírio. Lingua na mídia. $1^{\mathrm{a}}$ ed. São Paulo: Parábola Editorial, 2009. . Apresentação. In: . Introdução à linguística dominios e fronteiras. $9^{\mathrm{a}} \mathrm{ed}$. São Paulo:

Cortez, 2012.

RODRIGUES, Aryon Dall'Igna. Problemas relativos à descrição do português contemporâneo como língua padrão no Brasil. In: BAGNO, Marcos. Linguística da norma. $3^{a}$ ed. São Paulo: Edições Loyola, 2012.

SCHERRE, Maria Marta Pereita. Doa-se lindos filhotes de poodle: variação lingüística, mídia e preconceito. São Paulo: Parábola Editorial, 2006.

SILVEIRA, Bianca Alvin de Andrade. Jornalismo esportivo na midia local de Juiz de Fora: os limites da cobertura sobre a campanha do Tupi em 2006. Disponível em: http://www.ufjf.br/facom/files/2013/04/BiancaSilveira.pdf. Acesso em: 7 abr. 2017. TARALLO, Fernando. A pesquisa sociolinguística. 8a ed. São Paulo: Ática, 2007.

Recebido em: 28/02/2019

Aprovado em: 07/06/2019

Publicado em: 28/09/2019 